\title{
Kearifan Lokal Guna Pemecahan Masalah ${ }^{1}$
}

\author{
$(\text { Jusuf Nikolas Anamofa })^{2}$
}

\section{Pengantar}

Perubahan adalah keniscayaan dalam kehidupan manusia. Perubahan-perubahan yang terjadi bukan saja berhubungan dengan lingkungan fisik, tetapi juga dengan budaya manusia. Hubungan erat antara manusia dan lingkungan kehidupan fisiknya itulah yang melahirkan budaya manusia. Budaya lahir karena kemampuan manusia mensiasati lingkungan hidupnya agar tetap layak untuk ditinggali waktu demi waktu. Kebudayaan dipandang sebagai manifestasi kehidupan setiap orang atau kelompok orang yang selalu mengubah alam. Kebudayaan merupakan usaha manusia, perjuangan setiap orang atau kelompok dalam menentukan hari depannya. Kebudayaan merupakan aktivitas yang dapat diarahkan dan direncanakan (Van Peursen, 1976:10-11). Oleh sebab itu dituntut adanya kemampuan, kreativitas, dan penemuan-penemuan baru. Manusia tidak hanya membiarkan diri dalam kehidupan lama melainkan dituntut mencari jalan baru dalam mencapai kehidupan yang lebih manusiawi. Dasar dan arah yang dituju dalam perencanaan kebudayaan adalah manusia sendiri sehingga humanisasi menjadi kerangka dasar dalam strategi kebudayaan (Ali Moertopo,1978;12).

Dalam perspektif di atas, realitas yang sebenarnya adalah masa kini (present) dengan segala permasalahan yang dihadapkan kepada manusia di dalam lingkungan hidupnya. Masa kini sebagai realitas adalah hasil interaksi antara manusia dengan lingkungannya. Bila perubahan lingkungan fisik membuat manusia harus mensiasatinya dan melahirkan budaya-budaya yang terus menerus disesuaikan, maka perubahan-perubahan budaya itu juga mesti disiasati demi keberlangsungan hidup manusia.

Dengan pengakuan terhadap perubahan sebagai keniscayaan dan kemampuan manusia mensiasati lingkungan dan budayanya, maka kearifan lokal (local wisdom) bisa mendapatkan tempatnya sebagai bagian dari siasat kebudayaan itu. Makalah ini hendak mendiskusikan tentang posisi kearifan lokal sebagai pengetahuan lokal masyarakat dalam rangka pemecahan masalah masa kini (present problem solving).

\section{Tentang Kearifan Lokal}

Menelisik pengertian kearifan lokal, hal pertama yang perlu dilakukan adalah melihat pengertian kamus tentang istilah itu. Dalam pengertian kamus, kearifan lokal (local wisdom) terdiri dari dua kata: kearifan (wisdom) dan lokal (local). Dalam Kamus Inggris Indonesia John M. Echols dan Hassan Shadily, local berarti setempat, sedangkan wisdom (kearifan) sama dengan kebijaksanaan. Kearifan lokal secara sederhana dapat diartikan sebagai kebijaksanaan lokal.

Secara filosofis, kearifan lokal dapat diartikan sebagai sistem pengetahuan masyarakat lokal/pribumi (indigenous knowledge systems) yang bersifat empirik dan pragmatis. Bersifat empirik karena hasil olahan masyarakat secara lokal berangkat dari fakta-fakta yang terjadi di sekeliling kehidupan mereka. Bertujuan pragmatis karena seluruh konsep yang terbangun sebagai hasil olah pikir dalam sistem pengetahuan itu bertujuan untuk pemecahan masalah sehari-hari (daily problem solving).

\footnotetext{
${ }^{1}$ Disampaikan dalam Diskusi Mahasiswa Kristen Maluku Yogyakarta, 25 Juli 2010

${ }^{2}$ Mahasiswa Pascasarjana IImu Filsafat UGM Yogyakarta
} 
Dalam pengertian yang lebih luas, kearifan lokal dapat dipahami sebagai berikut:

"Local wisdom is the knowledge that discovered or acquired by local people through the accumulation of experiences in trials and integrated with the understanding of surrounding nature and culture" (Naritoom, --)

Naritoom mengartikan kearifan lokal sebagai pengetahuan yang terakumulasi karena pengalaman-pengalaman hidup, dipelajari dari berbagai situasi di sekeliling kehidupan manusia dalam suatu wilayah. Hal serupa dapat dilihat pada definisi yang dimunculkan dalam situs Wikipedia.com:

'Traditional knowledge, indigenous knowledge, and local knowledge generally refer to the matured long-standing traditions and practices of certain regional, indigenous, or local communities. Traditional knowledge also encompasses the local, knowledge, and teachings of these communities. In many cases, traditional knowledge has been orally passed for generations from person to person. Some forms of traditional knowledge are expressed through stories, legends, folklore, rituals, songs, and even laws. Other forms of traditional knowledge are often expressed through different means." (Wikipedia, 2010)

Dari definisi-definisi itu, kita dapat memahami bahwa kearifan lokal adalah pengetahuan yang dikembangkan oleh para leluhur dalam mensiasati lingkungan hidup sekitar mereka, menjadikan pengetahuan itu sebagai bagian dari budaya dan memperkenalkan serta meneruskan itu dari generasi ke generasi. Beberapa bentuk pengetahuan tradisional itu muncul lewat cerita-cerita, legenda-legenda, nyanyian-nyanyian, ritual-ritual, dan juga aturan atau hukum setempat.

Kearifan lokal menjadi penting dan bermanfaat hanya ketika masyarakat lokal yang mewarisi sistem pengetahuan itu mau menerima dan mengklaim hal itu sebagai bagian dari kehidupan mereka. Dengan cara itulah, kearifan lokal dapat disebut sebagai jiwa dari budaya lokal. Hal itu dapat dilihat dari ekspresi kearifan lokal dalam kehidupan setiap hari karena telah terinternalisasi dengan sangat baik. Tiap bagian dari kehidupan masyarakat lokal diarahkan secara arif berdasarkan sistem pengetahuan mereka, dimana tidak hanya bermanfaat dalam aktifitas keseharian dan interaksi dengan sesama saja, tetapi juga dalam situasi-situasi yang tidak terduga seperti bencana yang datang tiba-tiba.

Berangkat dari semua itu, kearifan lokal adalah persoalan identitas. Sebagai sistem pengetahuan lokal, ia membedakan suatu masyarakat lokal dengan masyarakat lokal yang lainnya. Perbedaan itu dapat dilihat dari tipe-tipe kearifan lokal yang dapat ditelusuri:

1. Kearifan lokal dalam hubungan dengan makanan: khusus berhubungan dengan lingkungan setempat, dicocokkan dengan iklim dan bahan makanan pokok setempat. (Contoh: Sasi laut di Maluku dan beberapa tempat lain sebagai bagian dari kearifan lokal dengan tujuan agar sumber pangan masyarakat dapat tetap terjaga).

2. Kearifan lokal dalam hubungan dengan pengobatan: untuk pencegahan dan pengobatan. (Contoh: Masing-masing daerah memiliki tanaman obat tradisional dengan khasiat yang berbeda-beda).

3. Kearifan lokal dalam hubungan dengan sistem produksi: Tentu saja berkaitan dengan sistem produksi lokal yang tradisional, sebagai bagian upaya pemenuhan kebutuhan dan manajemen tenaga kerja. (Contoh: Subak di Bali; di Maluku ada Masohi untuk membuka lahan pertanian, dll.). 
4. Kearifan lokal dalam hubungan dengan perumahan: disesuaikan dengan iklim dan bahan baku yang tersedia di wilayah tersebut (Contoh: Rumah orang Eskimo; Rumah yang terbuat dari gaba-gaba di Ambon, dll.).

5. Kearifan lokal dalam hubungan dengan pakaian: disesuaikan dengan iklim dan bahan baku yang tersedia di wilayah itu.

6. Kearifan lokal dalam hubungan sesama manusia: sistem pengetahuan lokal sebagai hasil interaksi terus menerus yang terbangun karena kebutuhan-kebutuhan di atas. (Contoh: Hubungan Pela di Maluku juga berhubungan dengan kebutuhan-kebutuhan pangan, perumahan, sistem produksi dan lain sebagainya).

\section{Tantangan Terhadap Kearifan Lokal}

Bila ada sistem pengetahuan lokal, maka ada juga sistem pengetahuan global. Apabila sistem pengetahuan lokal merupakan kategori pembeda antara suatu komunitas lokal dengan komunitas lokal yang lain, maka sistem pengetahuan global berupaya mengatasi semua pengetahuan lokal dan menjadikan semua masyarakat lokal terintegrasi ke dalam satu sistem pengetahuan saja. Apabila sistem pengetahuan lokal muncul dalam bentuk mitos-mitos tradisional, maka sistem pengetahuan global muncul pula dalam mitos-mitos modern. Salah satu mitos yang sangat terkenal, khususnya di negara-negara berkembang dan bekas jajahan adalah "pembangunan". Mitos pembangunan muncul guna membungkus ideologi "ekonomi politik pembangunan" negara-negara maju.

Definisi tentang pembangunan akan terus mengalami perubahan, disesuaikan dengan kebutuhan zaman. Tetapi pada umumnya, pembangunan diartikan sebagai suatu proses perubahan dari kondisi yang tidak baik menjadi yang lebih baik. Indikator-indikator yang menunjukkan suatu kondisi tidak baik tidak ditentukan begitu saja, tetapi ada prosesnya tersendiri. Dalam perspektif pembangunan secara umum, pembangunan ekonomi mendapatkan porsi yang lebih karena indikator kemajuan suatu negara adalah pertumbuhan ekonomi yang baik. Namun, untuk memahami pembangunan ekonomi, mesti melibatkan perspektif politik. Hal itu disebabkan karena perumusan kebijakan pembangunan merupakan proses politik yang melibatkan beragam aktor - mulai dari negara, birokrat, politisi, pengusaha, lembaga swadaya masyarakat hingga masyarakat itu sendiri - dengan beragam kepentingan pula, yang interaksinya bisa jadi saling berbenturan. Untuk mencapai hasil yang maksimal dalam mengatasi konflik tersebut, para aktor dituntut melakukan berbagai negosiasi dan kompromi. Dengan demikian untuk memahami kebijakan pembangunan dengan benar perlu ditelusuri secara cermat perilaku, motivasi atau pun preferensi para aktornya sehingga diperoleh jawaban: siapa memperoleh apa, berapa banyak, mengapa dan dengan cara bagaimana dari kebijakan pembangunan yang berlangsung di suatu negara dalam kurun waktu tertentu.

Dalam kerangka politik ekonomi pembangunan, kearifan lokal tidak mendapatkan tempat sama sekali karena telah disingkirkan oleh sistem pasar dan negara. Investasi demi pertumbuhan ekonomi negara adalah lebih penting daripada suatu tindakan berkelanjutan bagi masa depan manusia yang menjadi inti dari kearifan masyarakat lokal. Dalam beberapa kasus, bukan saja sistem pengetahuan lokal masyarakat yang terpinggirkan, tetapi juga masyarakat lokal secara fisik dipinggirkan atau direlokasi dengan alasan pembangunan. Selain itu, dengan alasan investasi pula, keamanan menjadi faktor penting dalam pembangunan. Struktur pengamanan dibangun sampai ke pelosok-pelosok negeri dengan melibatkan aparat-aparat negara yang 
cenderung tidak memahami cara-cara masyarakat lokal menyelesaikan sengketa di antara mereka.

Masyarakat lokal yang terorganisir dengan baik dan mendapatkan tempatnya dalam sistem pemerintahan negara Indonesia adalah negeri (desa). Negeri telah lama menjadi basis pertempuran antara masyarakat vs negara, sosialisme vs kapitalisme. Secara sosio-historis, negeri-negeri pada umumnya berbasis ekonomi sosialis (prakteknya mendahului istilah). Kepemilikan tanah dikelola secara komunal dengan semangat egalitarian dan pemerataan. Hukum adat tidak mengenal kepemilikan pribadi yang mutlak, yang dapat menimbulkan ketimpangan dalam sistem masyarakat tradisional. Hak-hak ulayat atau petuanan adat atas tanah menjadi contoh penting bagaimana pengelolaan tanah itu dilakukan di negeri-negeri adat.

Masalah muncul ketika sistem desa di Jawa dipaksakan untuk diberlakukan di luar Jawa. Di Jawa, telah lama terjadi penundukkan kerajaan terhadap desa dan membuat ketimpangan ekonomi-politik. Cerita-cerita lokal yang bisa diketahui melalui legenda atau sejarah menunjukkan dengan jelas bahwa desa sebagai wilayah dan komunitas lokal menjadi domain mutlak kerajaan. Raja di Jawa adalah penguasa pribadi yang melakukan pengendalian dan pemilikan atas desa beserta seluruh isinya, terutama tanah dan penduduknya secara absolut. Raja memiliki hak penggunaan kekerasan dengan aparat-aparat kerajaan yang terlatih untuk melakukan tindakan represi terhadap desa. Para penguasa lokal tunduk kepada raja dan harus memberikan upeti karena semua wilayah itu adalah milik raja. Ketika sistem desa diperkenalkan ke luar Jawa, maka jiwa dan semangat sebagai klien terhadap patron itu pun terbawa ke sana. Campur tangan negara mulai nyata dan merubah hampir seluruh sistem pemerintahan adat, dengan hukum-hukum adat yang berlaku.

Kondisi itu menjadi basis yang kuat bagi kolonialisme mengembangkan sistem kapitalis dan mengeksploitasi tanah dan penduduk desa. Kolonialismelah yang membawa sistem pengetahuan modern ke negara-negara jajahan, memperkenalkan dan mempraktekkannya.

\section{Posisi Kearifan Lokal Guna Pemecahan Masalah Masa Kini}

Tidak dapat dipungkiri, saat ini dunia mengalami permasalahan yang belum pernah dialami sebelumnya. Setelah terjadi dua kali perang dunia yang meluluhlantahkan segi-segi kemanusiaan, maka sistem pengetahuan modern yang menjadikan manusia dengan kemampuan rasionya sebagai tuan atas dirinya dan dunia pun mulai dikritik. Kritik-kritik itu datang karena ketidakmampuan rasio modern mengeliminasi kehancuran-kehancuran yang ditimbulkan akibat kepentingan di balik setiap penemuan-penemuan di bidang ilmu dan teknologi. Saat ini dunia kembali berhadapan dengan situasi lain, yaitu perubahan iklim yang tidak lagi menentu. Sekali lagi rasio modern yang menjadikan pembangunan sebagai salah satu proses penting mendapat tantangannya. Dengan alasan pembangunan, lingkungan tempat hidup manusia diobrak-abrik, kota-kota baru dibangun, tambang-tambang baru dibuka, hanya untuk memenuhi nafsu konsumsi manusia.

Pada tahap itulah, ketika manusia dengan rasio modernnya telah bingung berhadapan dengan alam karena sudah tidak mampu lagi menguasainya, kearifan lokal memperoleh tempatnya kembali. Keharmonisan dengan lingkunganlah yang dapat menjamin masa depan manusia. Hal itu tentu saja telah dibuktikan lewat proses panjang kehidupan leluhur dalam komunitaskomunitas lokal dalam mensiasati alam lewat budaya yang arif dan bijaksana. Dalam beberapa kasus, konflik di Maluku misalnya, ketika kemampuan pengetahuan ilmiah dalam hubungan 
dengan manajemen konflik sepertinya sudah tidak mampu menemukan solusi terbaik, hanya kearifan lokal yang menjadi titik balik semua itu.

\section{Penutup: Apa Yang Dapat Dilakukan?}

Makalah ini jauh dari sempurna, karena kalau telah sempurna maka tidak layak lagi didiskusikan. Setelah kearifan lokal dipahami berdasarkan definisi, tantangan dan posisinya dalam memecahkan masalah masa kini, pertanyaan penting yang muncul adalah apa yang dapat dilakukan terhadap semua itu?

Tentu saja itu menjadi tugas kita semua untuk mendiskusikannya, tetapi dalam perspektif saya, ada beberapa hal yang dapat dilakukan:

1. Inventarisir semua bentuk kearifan lokal yang saat ini dapat digunakan sebagai solusi terhadap suatu masalah (problem solving).

2. Pengakuan terhadap identitas lokal sangat dibutuhkan bukan karena keterikatan sematamata, tetapi karena ada kearifan lokal yang membedakan kita dengan orang lain.

3. Menghargai semua bentuk kearifan lokal yang kita miliki dengan cara memelihara dan meneruskannya kepada generasi ke generasi. Kearifan lokal itu adalah milik kita, walaupun orang lain meneliti dan mempelajarinya, tetapi situasi dan semangat untuk menjadikannya sebagai solusi dalam kehidupan setiap hari tidak akan mereka miliki.

Dalam bukunya tentang perjalanan Magellan mengelilingi dunia, Over The Edge of The World (2003: 13), Laurence Bergreen menulis:

Despite the overwhelming importance of spices to their economy, Europeans remained dependent on Arab merchants for their supply. They knew the European climate could not sustain these exotic spices. In the sixteenth century, the Iberian peninsula was far too cold-colder than it is now, in the grip of the Little Ice Age - and too dry to cultivate cinnamon, cloves, and pepper. An Indonesian ruler was said to have boasted to a trader who wanted to grow spices in Europe, "You may be able to take our plants, but you will never be able to take our rain."

\section{Referensi}

\section{Buku Sumber}

Ali, Moertopo,1978, Strategi Pembangunan Indonesia, CSIS, Jakarta.

Bergreen, Laurence, 2003, Over The Edge of The World, HarperCollins Publishers Inc.: NY.

Van Peursen, 1976, Strategi Kebudayaan, Kanisius, Yogyakarta.

Link Internet

Ekonomi Politik Pembangunan, (diakses tanggal 23 Juli 2010).

Eko, Sutoro, Ekonomi Politik Pembaharuan Desa, (diakses tanggal 24 Juli 2010). 
Naritoom, Chatcharee. Local Wisdom/Indigenous Knowledge System. Nakhon Pathom, Thailand: Kasetsart University. (diakses tanggal 23 Juli 2010). 